\title{
Variation in Flagellar Morphology of Vibro parahaemolyticus and Vibrio alginolyticus in Different Cultural Conditions
}

\author{
C. P. ANAND*1, Daiichi KaKImoto*2, and Taizo SAKATA ${ }^{* 2}$ \\ (Accepted January 25, 1982)
}

\begin{abstract}
Three strains, namely the $\mathbf{K}+$ and $\mathbf{K}-$ (Kanagawa positive and negative) strains of $V$. parahaemolyticus and a strain of $V$. alginolyticus were used to study the variation of flagellar morphology in different cultural conditions. All three strains showed M-(monotrichous) flagella in liquid media in different studies. But on solid media, the flagellar morphology varied depending on the type of media, levels of $\mathrm{pH}, \mathrm{NaCl}$ concentrations, growth temperatures and other cultural conditions. Examination of flagella during the growth period of the strains revealed that $V$. alginolyticus and $\mathbf{K}+$ strain of $\boldsymbol{V}$. parahaemolyticus first showed PM-flagella and then changed to P-(peritrichous) flagella, whereas $\mathbf{K}$-strain showed P-flagella throughout the growth period. The strains developed $\mathrm{M}$-flagella when they were grown on $\mathrm{TS} 3 \% \mathrm{NaCl}$ medium containing gelatin ( $7 \%$ ) and agar $(0.75 \%)$ as solidifying agents. However, the same strains showed either mixed type or P-flagella when they were grown on ZoBell $2216 \mathrm{E}$ medium made with either different concentrations of agar or carrageenan. It was observed that the relation between swarming and P-flagellation depended on cultural conditions. The results obtained in the present study indicate the need for standardization of cultural conditions when establishing flagellar morphology.
\end{abstract}

The flagellar morphology plays an important role in bacterial classification. Hence, the flagellar morphology should be established in different cultural conditions before it is used in the taxonomy of bacteria. SAKazaki et al. ${ }^{1)}$ reported that $V$. parahaemolyticus had a single polar flagellum. MrWATANI et al. $^{2)}$ observed sheathed polar flagellum of $V$. parahaemolyticus. BAUMANN et al., ${ }^{9,4)}$ Allen and BaUmanN, ${ }^{()}$NAKAMURA et $a l^{\left({ }^{8}\right)}$ and SAKATA et al. ${ }^{7}$ reported that $V$. parahaemolyticus or $V$. alginolyticus produced a polar monotrichous sheathed flagellum in a liquid medium and on a solid medium they produced in addition to single polar sheathed flagellum, unsheathed peritrichous flagella. SHINODA and OKAMOTO ${ }^{8)}$ studied the formation and function of lateral flagella in $V$. parahaemolyticus.

The study conducted so far on flagellar morphology of $V$. parahaemolyticus and $V$. alginolyticus is limited in the sense that the flagellar morphology has been studied on a certain medium at a definite $\mathrm{pH}$ and temperature, and there is no report on flagellar morphology in different cultural conditions. In view of the above, the present study was undertaken to study the variation of flagellar morphology in different cultural conditions.
Swarming in relation to flagellar morphology was studied. The Kanagawa positive and negative strains of $V$. parahaemolyticus were compared from the point of variability in flagellar morphology.

\section{Materials and Methods}

\section{Strains}

Three strains; a Kanagawa positive (VPHK6,03: K6) and a Kanagawa negative (VPFK46, 06: K46) strains of $V$. parahaemolyticus, and a strain of $V$. alginolyticus (VAF2. NIH 155-78) were used in the study. The source and maintenance of the strains have been described by ANAND et al..$^{\text {g) }}$

\section{Inocula}

A $24 \mathrm{~h}$ culture of Trypticase Soy Broth supplemented with $3 \% \mathrm{NaCl}$ was used for inoculation in different cultural studies. Controls were run in all experiments.

\section{Cultural Conditions}

Media

For studying flagellar morphology in different

*1 Laboratory of Marine Biochemistry, Faculty of Agriculture, The University of Tokyo, Bunkyo, Tokyo 113, Japan (C. P. ANAND：東京大学费学部水産化学研究宝).

*2 Laboratory of Microbiology, Faculty of Fisheries, Kagoshima University, Kagoshima 890, Japan (柿本 大壱・坂田泰造：鹿児島大学水应学部微生物学研究室). 
media, the following media were used: a) ZoBell $2261 \mathrm{E}$ agar and broth (the composition of which has been described in the previous paper ${ }^{8)}$ ) b) Trypticase Soy agar and broth (Baltimore Biological Labs.) supplemented with $3 \% \mathrm{NaCl}$ c) BTB teepol agar (Eiken Chemical Co.) d) TCBS agar (Eiken) e) Vibrio agar (Nissui Chemical Co.). In addition, for making semisolid medium, ZoBell $2216 \mathrm{E}$ medium with $0.6 \%$ agar was used.

\section{$p \mathrm{H}, \mathrm{NaCl}$ and Temperature}

For examining flagellar morphology of strains grown in different $\mathrm{pH}(6,7.5$ and 9$), \mathrm{NaCl}$ concentrations $(1,3,5$ and $7 \%$ ) and temperatures $\left(18,2125,37\right.$ and $\left.42^{\circ} \mathrm{C}\right), \mathrm{ZoBell} 2216 \mathrm{E}$ agar and broth media were used. The flagellar were examined after incubating the streaked plates and broth tubes at 25 and $37^{\circ} \mathrm{C}$ for $18 \mathrm{~h}$.

\section{Artificial Sea Water (ASW)}

To study the influence of ASW, ZoBell $2216 \mathrm{E}$ agar and Trypticase Soy agar with $3 \% \mathrm{NaCl}$ media were used. In addition, the same ZoBell medium with $3 \% \mathrm{NaCl}$ instead of ASW and TSA medium with ASW instead of $3 \% \mathrm{NaCl}$ were used. The flagella were examined after incubating the streaked plates for $18 \mathrm{~h}$ at 25 and $37^{\circ} \mathrm{C}$.

\section{Incubation Time}

Morphology of flagella at different incubation times were examined using ZoBell 2216E agar medium. The flagella were examined after incubating the streaked plates for $6,12,18,24$ and $38 \mathrm{~h}$ at $37^{\circ} \mathrm{C}$.

\section{Effect of Solidifying Agents}

Flagellar morphology of cells grown on ZoBell $2216 \mathrm{E}$ medium made with $0.5,1.0,1.5$ and $2.0 \%$ agar was observed after $18 \mathrm{~h}$ of incubation at 25 and $37^{\circ} \mathrm{C}$. The viscosity of ZoBell $2216 \mathrm{E}$ medium made with $1.5 \%$ agar was increased by adding $1 \%$ carboxymethyl cellulose ( $\mathrm{Na}$ salt, Wako) and flagella were examined after $18 \mathrm{~h}$ of incubation at 25 and $37^{\circ} \mathrm{C}$. Gelatin $(7 \%)$ in combination with agar $(0.75 \%)$ was used as solidifing agent in
TSB $3 \% \mathrm{NaCl}$ medium to see if it exerts any influence on flagellar morphology of the strains. The flagella were examined after incubating plates for $24 \mathrm{~h}$ at 15 and $21^{\circ} \mathrm{C}$.

ZoBell 2216E solid medium was made with $1.5 \%$ carrageenan (Matsumoto Co.) as solidifying agent and the strains were examined for flagella after incubating the streaked plates for $18 \mathrm{~h}$ at 25 and $37^{\circ} \mathrm{C}$.

\section{Swarming}

Streak plate method was used to observe swarming on solid media in different cultural conditions.

\section{Examination of Flagella}

The flagella were examined by means of an electron microscope. Bacterial samples were placed on collodion coated, carbon coated 150 mesh copper grids. The grids were stained negatively with $1 \%$ potassium phosphotungstate $(\mathrm{pH}$ 7.0). The specimens were observed in a Hitachi H-300 electron microscope at an accelerating voltage of $75 \mathrm{KV}$.

\section{Results}

\section{Flagellar Morphology in Different Cultural Condi- tions}

\section{Media}

As seen in Table 1, all strains showed peritrichous (P) flagella at 25 and $37^{\circ} \mathrm{C}$ on solid media of ZoBell 2216E (Fig. A) and TSA $3 \% \mathrm{NaCl}$, while in liquid media they showed monotrichous $(\mathrm{M})$ flagella at both the temperatures. In the case of Vibrio agar, BTB Teepol and TCBS solid media (Fig. B and $C$ ), all the strains showed M-flagella at both 25 and $37^{\circ} \mathrm{C}$. The amount of P-flagella as observed on grids in the electron microscope was more when ZoBell 2216E medium was used than when TSA $3 \% \mathrm{NaCl}$ medium was used. On semi solid medium of ZoBell $2216 \mathrm{E}$ with $0.6 \%$ agar, the strains showed a mixed monotrichous and peritrichous flagellation; the Kanagawa negative strain show-

Table 1. Flagellar morphology of strains grown in different media

\begin{tabular}{|c|c|c|c|c|c|c|c|c|c|c|c|c|c|c|}
\hline \multirow{3}{*}{$\begin{array}{l}\text { Medium } \\
\text { Incubation } \\
\text { temp. }{ }^{\circ} \mathrm{C}\end{array}$} & \multirow{2}{*}{\multicolumn{2}{|c|}{ BTB agar }} & \multirow{2}{*}{\multicolumn{2}{|c|}{ TCBS agar }} & \multirow{2}{*}{\multicolumn{2}{|c|}{ Vibrio agar }} & \multicolumn{4}{|c|}{ ZoBell $2216 \mathrm{E}$} & \multicolumn{4}{|c|}{$\mathrm{TS}+3 \% \mathrm{NaCl}$} \\
\hline & & & & & & & \multicolumn{2}{|c|}{ agar } & \multicolumn{2}{|c|}{ broth } & \multicolumn{2}{|c|}{ agar } & \multicolumn{2}{|c|}{ broth } \\
\hline & 25 & 37 & 25 & 37 & 25 & 37 & 25 & 37 & 25 & 37 & 25 & 37 & & 37 \\
\hline \multicolumn{15}{|l|}{ Strain } \\
\hline VAF2 & $M^{* 1}$ & $\mathbf{M}$ & $\mathbf{M}$ & $\mathbf{M}$ & M & $\mathbf{M}$ & $P^{* 2}$ & $\mathbf{P}$ & $\mathbf{M}$ & M & $\mathbf{P}$ & $\mathbf{P}$ & $\mathbf{M}$ & M \\
\hline VPHK6 & $\mathbf{M}$ & M & $\mathbf{M}$ & $\mathbf{M}$ & $\mathbf{M}$ & $\mathbf{M}$ & $\mathbf{P}$ & $\mathbf{P}$ & $\mathbf{M}$ & $\mathbf{M}$ & $\mathbf{P}$ & $\mathbf{P}$ & $\mathbf{M}$ & M \\
\hline VPFK46 & M & $\mathbf{M}$ & M & $\mathbf{M}$ & $\mathbf{M}$ & $\mathbf{M}$ & $\mathbf{P}$ & $\mathbf{P}$ & $\mathbf{M}$ & M & $\mathbf{P}$ & $\mathbf{P}$ & $\mathbf{M}$ & $\mathbf{M}$ \\
\hline
\end{tabular}

*1 Monotrichous flagella.

*2 Peritrichous flagella. 
ed PM-flagella (cells with P-flagella more than with M-flagella), where as the other two strains showed MP-flagella (cells with M-flagella more than with P-flagella).

\section{$\mathrm{pH}, \mathrm{NaCl}, \mathrm{ASW}$ and Temperature}

In liquid medium, all cultures showed M-flagella at all $\mathrm{pH}(6,7.5$ and 9), $\mathrm{NaCl}$ concentrations (1, 3, 5 and $7 \%$ ) and temperatures $(18,21,25,37$ and $42^{\circ} \mathrm{C}$ ) used in the study. On solid medium, the flagellar morphology varied. In $\mathrm{pH}$ studies, at $25^{\circ} \mathrm{C}$, the flagellation of $V$. parahaemolyticus strains (both $\mathrm{K}+$ and $\mathrm{K}-$ ) changed from $\mathrm{M}$-type at $\mathrm{pH} 6$ to P-type at pH 7.5 and then to MP-type at pH 9. Whereas $V$. alginolyticus showed MPflagella at $\mathrm{pH} 6$, P-flagella at $\mathrm{pH} 7.5$ and PMflagella at pH 9 (Table 2). At $37^{\circ} \mathrm{C}, V$. alginolyticus and $\mathrm{K}+$ strain of $V$. parahaemolyticus showed $M$, $P$ and again M-flagella at $6,7.5$ and 9 respectively (Fig. D). The $\mathrm{K}$ - strain showed $\mathrm{M}$-flagella at $\mathrm{pH}$ 6 and P-flagella at $\mathrm{pH} 7.5$ and 9 . The study with $\mathrm{NaCl}$ concentrations at 25 and $37^{\circ} \mathrm{C}$ (Table 3) indicated that while all the strains developed $\mathbf{P}$ flagella at $3 \% \mathrm{NaCl}$ and $\mathrm{M}$-flagella at $7 \% \mathrm{NaCl}$,

Table 2. Flagellar morphology of strains grown at different $\mathrm{pH}$ on solid medium

\begin{tabular}{|c|c|c|c|c|c|c|}
\hline \multirow{2}{*}{$\begin{array}{l}\text { Incubation } \\
\text { temp. }{ }^{\circ} \mathrm{C} \\
\text { pH }\end{array}$} & \multicolumn{3}{|c|}{25} & \multicolumn{3}{|c|}{37} \\
\hline & 6.0 & 7.5 & 9.0 & 6.0 & 7.5 & 9.0 \\
\hline \multicolumn{7}{|l|}{ Strain } \\
\hline VAF2 & $M P^{* 1}$ & $\mathrm{p}$ & $\mathrm{PM}^{\neq 2}$ & $\mathbf{M}$ & $\mathbf{P}$ & $\mathbf{M}$ \\
\hline VPHK6 & $\mathbf{M}$ & $\mathbf{P}$ & MP & $\mathbf{M}$ & $\mathbf{P}$ & $\mathbf{M}$ \\
\hline VPFK46 & $\mathbf{M}$ & $\mathbf{P}$ & MP & $\mathbf{M}$ & $P$ & $\mathbf{P}$ \\
\hline
\end{tabular}

Table 3. Flagellar morphology of strains grown on solid medium at different $\mathrm{NaCl}$ concentrations

\begin{tabular}{|c|c|c|c|c|c|c|c|c|}
\hline \multirow{2}{*}{$\begin{array}{c}\text { Incubation } \\
\text { temp. }{ }^{\circ} \mathrm{C} \\
\mathrm{NaCl} \text { Conc. } \%\end{array}$} & \multicolumn{4}{|c|}{25} & \multicolumn{4}{|c|}{37} \\
\hline & 1 & 3 & 5 & 7 & 1 & 3 & 5 & 7 \\
\hline \multicolumn{9}{|l|}{ Strain } \\
\hline VAF2 & $\mathbf{P}$ & $\mathbf{P}$ & MP & $\mathbf{M}$ & $\mathbf{M}$ & $P$ & PM & $\mathbf{M}$ \\
\hline VPHK6 & PM & $\mathbf{P}$ & PM & $\mathbf{M}$ & PM & $\mathbf{P}$ & PM & $\mathbf{M}$ \\
\hline VPFK 46 & PM & $\mathbf{P}$ & MP & $\mathbf{M}$ & $\mathbf{M}$ & $\mathbf{P}$ & MP & $\mathbf{M}$ \\
\hline
\end{tabular}

Table 4. Flagellar morphology of strains grown at different temperatures on solid medium

\begin{tabular}{lccccc}
\hline \multicolumn{1}{c}{ Temp. ${ }^{\circ} \mathrm{C}$} & 18 & 21 & 25 & 37 & 42 \\
\hline Strain & & & & & \\
VAF2 & MP & MP & P & P & M \\
VPHK6 & PM & PM & P & P & M \\
VPFK46 & PM & PM & P & P & M \\
\hline
\end{tabular}

the flagellar type was different at 1 and $5 \% \mathrm{NaCl}$ concentrations in all the three strains. At $25^{\circ} \mathrm{C}$, $V$. alginolyticus showed $\mathbf{P}$ and MP-flagella respectively at 1 and $5 \% \mathrm{NaCl}$ concentrations; whereas the strains of $V$. parahaemolyticus showed PM and MP-flagella at 1 and $5 \% \mathrm{NaCl}$ concentrations, respectively. At $37^{\circ} \mathrm{C}, V$. alginolyticus developed flagella of $\mathbf{M}$-type at $1 \%$ (Fig. E) and PM-type at $5 \% \mathrm{NaCl}$ concentrations. While the $\mathrm{K}+$ strain of $V$. parahaemolyticus showed PM-type at $1 \%$ and MP-type at $5 \%, \mathrm{~K}$ - strain showed $\mathrm{M}$ and MP-flagella at 1 and $5 \% \mathrm{NaCl}$ concentrations, respectively.

When the strains were cultivated on ZoBell $2216 \mathrm{E}$ medium made with either ASW or $3 \%$ $\mathrm{NaCl}$ and flagella were examined, there was no difference in flagellar type. The same result was obtained with TSA medium made with either ASW or $3 \% \mathrm{NaCl}$. This observation showed that mineral components of ASW besides $\mathrm{NaCl}$ did not exert any influence on variation in flagellar type.

When the strains were grown at different temperatures and flagella were examined (Table 4), all the three strains showed P-flagella at 25 and $37^{\circ} \mathrm{C}$, but at $42^{\circ} \mathrm{C}$ they showed M-flagella. AT 18 and $21^{\circ} \mathrm{C}, V$. alginolyticus showed MP-flagella; whereas the strains of $V$. parahaemolyticus showed PM-flagella.

\section{Incubation Time}

The flagellar morphology of the strains at different incubation times $(6,12,1824$ and $36 \mathrm{~h})$, grown at $37^{\circ} \mathrm{C}$ on ZoBell $2216 \mathrm{E}$ agar, was examined to see if there was any change in flagellar type during their growth period. $V$. alginolyticus first showed PM-fiagella in $6 \mathrm{~h}$ culture and then changed to $\mathbf{P}$-flagella at other incubation times (Fig. I and J). The $\mathrm{K}+$ strain of $V$.parahaemolyticus showed PM-flagella in 6 and $12 \mathrm{~h}$ cultures and after that time it changed to P-flagella. The K - strain showed P-flagella throughout the growth period (Fig. F, G and $\mathrm{H}$ ). In $38 \mathrm{~h}$ culture though the flagella were P-type in all the strains, many cells were found to be deflagellated (Fig. K).

\section{Effect of Solidifying Agents}

When agar was used as solidifying agent in ZoBell $2216 \mathrm{E}$ medium at different concentrations $(0.5,1,1.5$ and $2 \%)$, the flagellar type of the strains varied with respect to the concentrations used (Table 5). It also slightly depended on the growth temperature of the strains. At $25^{\circ} \mathrm{C}$, all the three strains showed P-flagella at 1 and $1.5 \%$ concentrations. At 0.5 and $2 \%$ concentrations, $V$. alginolyti- 


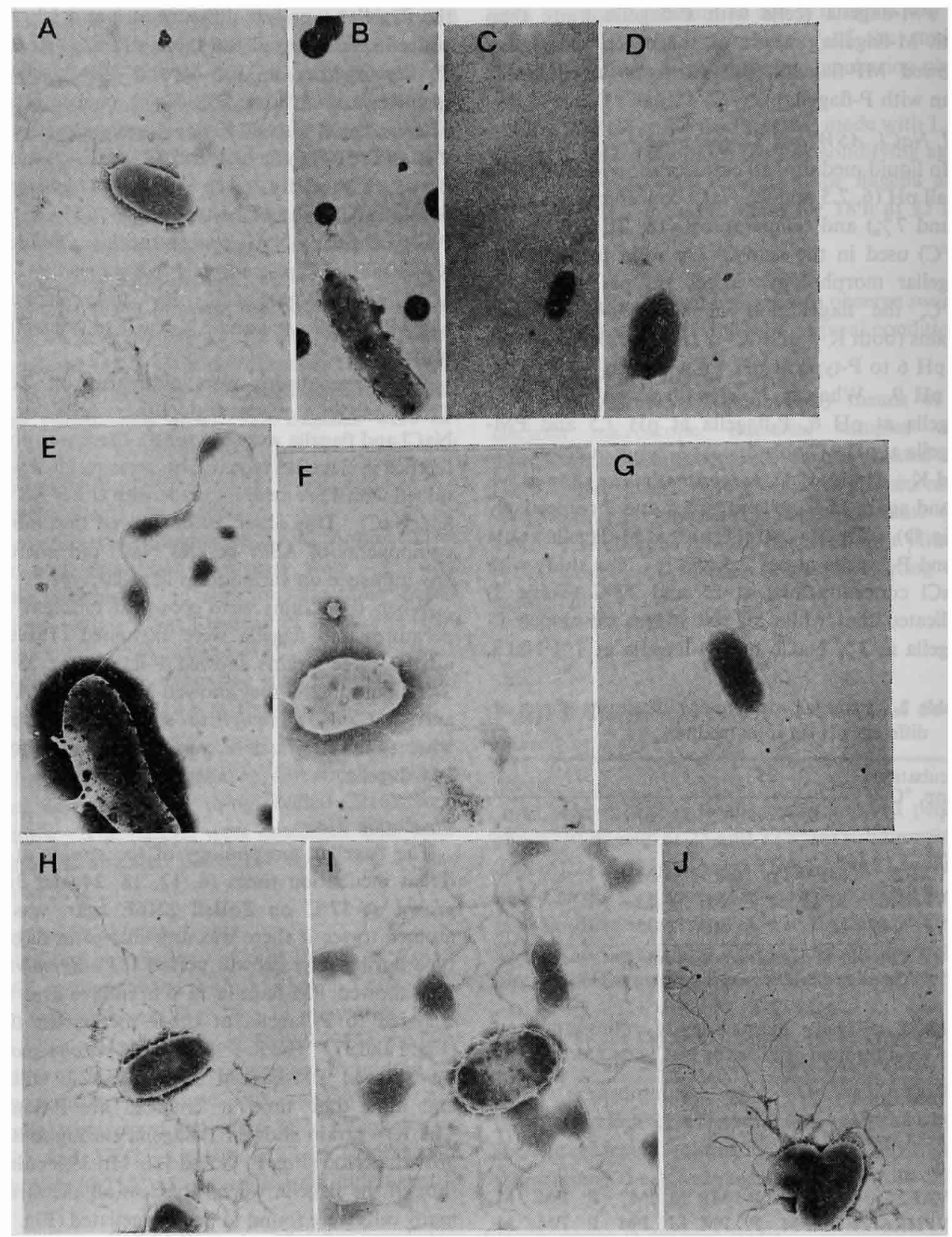

Fig. A to M. Electron micrographs. Cells were negatively stained.

Fig. A. $\mathrm{K}+$ strain of $V$. parahaemolyticus (VPHk6), grown on ZoBell 2216E solid medium at $25^{\circ} \mathrm{C}, \times 3500$

Fig. B. VPHk6, grown on BTB Teepol solid medium at $25^{\circ} \mathrm{C} . \quad \times 4900$

Fig. C. VPHk6, grown on TCBS solid medium at $25^{\circ} \mathrm{C} . \times 350$

Fig. D. VPHk6, grown on ZoBell $2216 \mathrm{E}(\mathrm{pH} 6)$ solid medium at $37^{\circ} \mathrm{C} . \quad \times 7000$

Fig. E. V. alginolyticus, grown on ZoBell $2216 \mathrm{E}(1 \% \mathrm{NaCl})$ solid medium at $37^{\circ} \mathrm{C} . \quad \times 7000$

Fig. F. $\mathrm{K}+$ strain of $V$. parahaemolyticus (VPFk46), $12 \mathrm{~h}$ incubation, grown on ZoBell 2216E agar at $37^{\circ} \mathrm{C} . \quad \times 4900$

Fig. G. VPFk $46,6 \mathrm{~h}$ incubation, grown on ZoBell $2216 \mathrm{E}$ agar at $37^{\circ} \mathrm{C} . \quad \times 7000$

Fig. H. VPFk46, $18 \mathrm{~h}$ incubation, grown on ZoBell $2216 \mathrm{E}$ agar at $37^{\circ} \mathrm{C} . \quad \times 7000$

Fig. I. V. alginolyticus (VAF2), $12 \mathrm{~h}$ incubation, grown on ZoBell $2216 \mathrm{E}$ agar at $37^{\circ} \mathrm{C} . \quad 7000$

Fig. J. VAF2, $38 \mathrm{~h}$ incubation, grown on ZoBell $2216 \mathrm{E}$ agar at $37^{\circ} \mathrm{C} . \quad \times 4900$ 

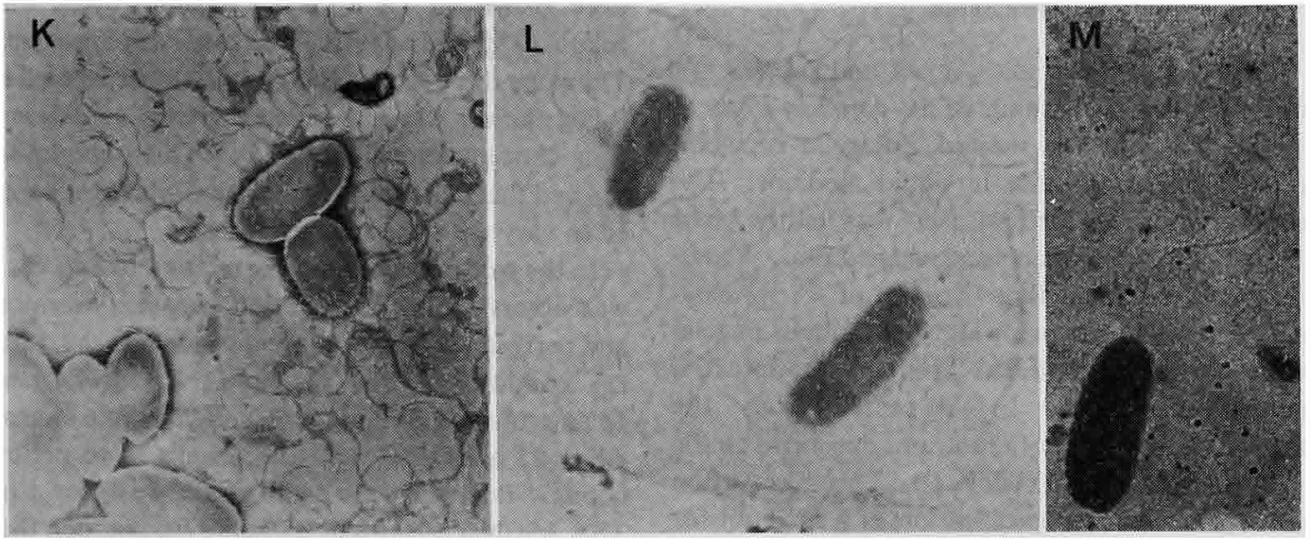

Fig. K. VAF2, $38 \mathrm{~h}$ incubation, grown on ZoBell $2216 \mathrm{E}$ agar at $25^{\circ} \mathrm{C} . \quad \times 3500$

Fig. L. VAF2, grown on ZoBell $2216 \mathrm{E}+1.5 \%$ carrageenan solid medium at $37^{\circ} \mathrm{C} . \quad \times 7000$

Fig. M. VPHk6, grown on TSB $3 \% \mathrm{NaCl}+7 \%$ gelatin $+0.75 \%$ agar solid medium at $21^{\circ} \mathrm{C}$. $\times 4900$

Table 5. Flagellar morphology of strains grown at different agar concentrations

\begin{tabular}{|c|c|c|c|c|c|c|c|c|}
\hline \multirow{2}{*}{$\begin{array}{c}\text { Incubation } \\
\text { temp. }{ }^{\circ} \mathbf{C} \\
\text { Agar conc. \% }\end{array}$} & \multicolumn{4}{|c|}{25} & \multicolumn{4}{|c|}{37} \\
\hline & 0.5 & 1.0 & 1.5 & 2.0 & 0.5 & 1.0 & 1.5 & 2.0 \\
\hline Strain & & & & & & & & \\
\hline VAF2 & MP & $\mathbf{P}$ & $\mathbf{P}$ & MP & MP & M & $\mathbf{P}$ & P \\
\hline VPHK6 & MP & $\mathbf{P}$ & P & PM & MP & MP & $\mathbf{P}$ & MP \\
\hline VPFK46 & PM & $\mathbf{P}$ & $\mathbf{P}$ & MP & PM & P & $P$ & MP \\
\hline
\end{tabular}

cus showed MP-flagella, $\mathrm{K}+$ strain of $V$. parahaemolyticus showed MP and PM-flagella, and Kstrain showed PM and MP-flagella, respectively. At $37^{\circ} \mathrm{C}$, the flagellar type of $V$. alginolyticus, $\mathrm{K}+$ and $\mathrm{K}$ - strains of $V$. parahaemolyticus was respectively MP, M, P and P; MP, MP, $\mathrm{P}$ and MP; $\mathrm{PM}, \mathrm{P}, \mathrm{P}$ and $\mathrm{MP}$ at $0.5,1,1.5$ and $2 \%$ agar concentrations. When viscosity of the ZoBell $2216 \mathrm{E}$ medium made with $1.5 \%$ agar was increased by adding $1 \%$ carboxymethyl cellulose, all the three strains developed P-flagella at both 25 and $37^{\circ} \mathrm{C}$. The amount of P-flagella was more when observed visually on the grids in the electron microscope.

When gelatin $(7 \%)$ alone was used, it was liquified by the strains during incubation. Hence, gelatin $(7 \%)$ in combination with agar $(0.75 \%)$ was used as solidifying agent in TSB $3 \% \mathrm{NaCl}$ medium. Surprisingly, all strains showed M-flagella at both 15 and $21^{\circ} \mathrm{C}$ (Fig. M).

When carrageenan at $1.5 \%$ concentration was used as solidifying agent instead of agar in ZoBell $2216 \mathrm{E}$ medium, all the three strains showed Pflagella (Fig. L).

\section{Swarming}

When the strains were grown on ZoBell $2216 \mathrm{E}$ medium at 25 and $37^{\circ} \mathrm{C}, V$. alginolyticus swarmed rapidly, $\mathrm{K}$ - strain of $V$.parahaemolyticus swarmed slowly and $\mathrm{K}+$ strain did not swarm at both the temperatures. The examination of flagella showed that they were all peritrichous. The strains of $V$. parahaemolyticus did not swarm on TSA $3 \%$ $\mathrm{NaCl}$ plates at both 25 and $37^{\circ} \mathrm{C}$ but $V$. alginolyticus swarmed only at $25^{\circ} \mathrm{C}$ and not at $37^{\circ} \mathrm{C}$. The flagella were P-type in all the strains. It was observed that all the three strains did not swarm at 18 and $42^{\circ} \mathrm{C}$, and the flagella of the strains were either mixed MP or PM and M-type at the respective growth temperatures. It was also observed that while $V$. alginolyticus swarmed on TSA $1 \% \mathrm{NaCl}$ plates at both 25 and $37^{\circ} \mathrm{C}, \mathrm{K}-$ strain of $\boldsymbol{V}$. parahaemolyticus swarmed only at $25^{\circ} \mathrm{C}$ but not at $37^{\circ} \mathrm{C}$. When flagella were examined $V$. alginolyticus showed peritrichous at $25^{\circ} \mathrm{C}$ and monotrichous at $37^{\circ} \mathrm{C}$ while $\mathrm{K}-$ strain of V. parahaemolyticus showed mixed PM-type at $25^{\circ} \mathrm{C}$ and M-type at $37^{\circ} \mathrm{C}$. 


\section{Discussion}

BAUMANN et al., ${ }^{3,4}$ and ALLEN and BAUMANN ${ }^{33}$ observed that the strains of $V$. parahaemolyticus and $V$. alginolyticus showed P-flagella on solid medium and M-flagella in liquid medium. The medium used in their studies was either yeast exctract of Difco marine agar medium. YABUUCHI et al. ${ }^{10)}$ found that the cells of $V$. parahaemolyticus had both polar and peritrichous flagella when grown on modified MOF agar after $16 \mathrm{~h}$ incubation at $20^{\circ} \mathrm{C}$. In the present study, the flagellar morphology of the strains depended on the type of medium used (Table 1). This observation calls for a need for specification of a medium for establishing flagellar morphology if shape and arrangement of flagella is considered as a criterion in the classification of bacteria. The reason for showing M-flagella on Vibrio agar, BTB Teepol and TCBS solid media, in the present study, may be due to composition of the medium coupled with high $\mathrm{pH}(>8)$ used in the medium.

SHINODA and OKAMOTO ${ }^{8)}$ observed that on solid medium cells of $V$. parahaemolyticus formed lateral flagella at both 37 and $25^{\circ} \mathrm{C}$, although at $37^{\circ} \mathrm{C}$ they became dissociated from the cells and decomposed in the medium. ULITZUR ${ }^{11)}$ reported that temperatures above $28^{\circ} \mathrm{C}$ inhibited the formation of peritrichous flagella by $V$. alginolyticus. It was observed in our study that at 18 and $21^{\circ} \mathrm{C}$, the strains developed mixed type flagellation; at $42^{\circ} \mathrm{C}$, M-flagellation; and at 25 and $37^{\circ} \mathrm{C}$ P-flagellation although some cells were found to be deflagellated at $37^{\circ} \mathrm{C}$.

When flagella were examined at different incubation times, all strains showed P-flagellation at $24 \mathrm{~h}$ but at $38 \mathrm{~h}$, though the flagella were P-type, many cells were found to be deflagellated. This observation differs from the result obtained by SHINoDA and OxAmoto ${ }^{8)}$ who found that cells of $V$. parahaemolyticus after cultivation at $37^{\circ} \mathrm{C}$ for $18 \mathrm{~h}$ had no lateral flagella, although the amount of lateral flagella was maximum in $6 \mathrm{~h}$ culture.

SHINODA and OKAмото ${ }^{8)}$ also found that when $V$. parahaemolyticus was grown at different agar concentrations, the amount of lateral flagella was maximum at $0.9 \%$, but it decreased at $1.2 \%$ and then again slightly increased at $1.5 \%$. They have not conducted study at $2 \%$ agar. It was noted in the present study that at $25^{\circ} \mathrm{C}$, all the three strains showed P-flagella at 1 and $1.5 \%$ agar and mixed type flagellation at 0.5 and $2 \%$ agar concentrations (Table 5).

All the three strains showed M-flagella when they were grown on $\mathrm{TS} 3 \% \mathrm{NaCl}$ medium made with gelatin $(7 \%)$ and agar $(0.75 \%)$ as solidifying agents. The same three strains showed either mixed type or P-flagellation when they were grown at different agar concentrations (Table 5). This observation showed that gelatin in combination with agar seemed to vary the type of flagellation.

In the study on swarming in relation to flagella, it was observed that the relation between swarming and peritrichous flagellation depended on the cultural conditions. For example, $V$. alginolyticus when grown on ZoBell $2216 \mathrm{E}$ solid medium swarmed at 25 and $37^{\circ} \mathrm{C}$, and the flagella were peritrichous. But when the same strain was grown on TSA $1 \% \mathrm{NaCl}$ plates at 25 and $37^{\circ} \mathrm{C}$, though they swarmed at both the temperatures, the flagellation was peritrichous at $25^{\circ} \mathrm{C}$ and monotrichous at $37^{\circ} \mathrm{C}$. This result differs from the result of ULITZUR ${ }^{11}$ ) who found that temperatures above $28^{\circ} \mathrm{C}$ inhibited both the formation of peritrichous flagella and swarming in $V$. alginolyticus. It can be said from the observations made in the present study that swarming need not always be related to peritrichous flagellation. In conclusion, the results obtained in the present study indicate the need for standardization of cultural conditions for establishing flagellar morphology.

\section{References}

1) R. SAKAZAKI, S. IWATANI, and H. Fukumi: Japan. J. Med. Sci. Biol., 16, 161-188 (1963).

2) T. Miwatani, S. Shinoda, and T. Fujino: Biken $J .$, 13, 146-155 (1970).

3) P. Baumann, L. Baumann, and M. Mandel: J. Bacteriol., 107, 268-294 (1971).

4) P. Baumann, L. Baumann, and J. L. Reichelt: J. Bacteriol., 113, 114-1155 (1973).

5) R. D. Allen and P. BaUmanN: J. Bacteriol. 107, 295-302 (1971).

6) K. Nakamura, D. Kakimoto, J. SwafFord, and R. Johnson: Bull. Japan. Soc. Sci. Fish., 45, 135142 (1979).

7) T. Sakata, M. Shimizu, and D. Kakimoto: Mem. Fac. Fish. Kagoshima Univ., 30, 339-347 (1981).

8) S. Shinoda and K. OKamoto: J. Bacteriol., 129, 1266-1271 (1977).

9) C. P. Anand, D. Kakimoto, and T. Sakata: Bull. Japan. Soc. Sci. Fish., 47, 539-545 (1981).

10) E. YaBuUChI, T. Miwatani, Y. TAKEDA, and M. ARITA: in "Proceedings of the International Symposium on $V$. parahaemolyticus" (ed. by $\mathrm{T}$. Fujino, G. Sakaguchi, R. Sakaguchi, R. SakaZAKI, and Y. TAKEDA), Saikon Publishing Co., Tokyo, 1974, pp. 163-168.

11) S. Ulitzur: Arch. Microbiol., 104, 285-288 (1975). 